\title{
A 3D NUMERICAL MODELING OF HEMISPHERICAL CONTACT AGAINST AN ELASTIC-PLASTIC FLAT SURFACE
}

\begin{abstract}
This paper presents a method of determining the anisotropic friction model for sheet metal forming processes based on experimental data obtained from the pinon-disk tribometer test. The frictional investigations presented in this work were conducted for deep drawing quality cold-rolled steel sheet. The anisotropic friction model corresponded to experimental results was implemented into a finite element (FE) model built using the ABAQUS software. In the numerical investigations the hemispherical contact against an elastic-plastic flat was analysed. Both material and friction anisotropy influenced the non-uniformity of the stress distribution around the hemisphere axis, which is clearly visible for higher values of hemispherical solid indentations. It was found that the change of isotropic friction to anisotropic conditions for both material models slightly influences - the value and change of equivalent plastic strain distribution in contact zone.
\end{abstract}

Keywords: anisotropy, contact modeling, elastic-plastic contact, friction modeling, friction anisotropy

\section{Introduction}

The frictional behaviour depends on several parameters such as the contact pressure, sliding velocity, tools and sheet surface roughness as well as lubricant conditions. Moreover, frictional resistance depends on physical and chemical factors acting on the contact surface, dynamics of the loads and the temperature [1-3]. The origin of this anisotropy can be attributed to two different sources. The first one is the material itself where the anisotropies of the materials consti-

\footnotetext{
${ }^{1}$ Autor do korespondencji/corresponding author: Tomasz Trzepieciński, Rzeszow University of Technology, 8 Powstańców Warszawy Avenue, 35-959 Rzeszow, Poland, tel.: (17) 8651714, e-mail: tomtrz@prz.edu.pl

${ }^{2}$ Feliks Stachowicz, Rzeszow University of Technology, e-mail: stafel@ prz.edu.pl

${ }^{3}$ Sergei Bosiakov, Belarusian State University, e-mail: bosiakov@bsu.by

${ }^{4}$ Sergei Rogosin, Belarusian State University, e-mail: Rogosin@bsu.by
} 
tuting the bodies manifest themselves on the contact surface. The second one is technological. The industrial process used to fabricate the bodies can create striations along preferential directions. Currently, there are not so many publications focusing on frictional anisotropy and its implementation in numerical simulations of sheet metal forming processes. Attention should be paid to the work of Hjiaj et.al. [4] where isotropic Coulomb's frictional contact law to anisotropic friction conditions with non-associated sliding rule was generalized. Based on a model of rigid anisotropic asperities, a theoretical investigation on friction limit surfaces and sliding rules has been carried out by Mróz and Stupkiewicz [5]. Effect of strain hardening on the elastic-plastic contact of a deformable sphere against a rigid flat under full stick contact condition is studied by Chatterje and Saho [6]. They have also made a comprehensive review of literature on models of elastic-plastic contact.

Most of friction models are completely defined by the friction conditions which specify a set of admissible contact forces and the sliding rule which stipulates what directions of sliding are allowed [4]. The limit surface is usually assumed to be isotropic predicting a frictional behaviour independent of the sliding direction. For many industrial applications, this assumption seems to be unrealistic and many experimental studies show that the frictional behaviour can change drastically with the sliding direction, requiring an anisotropic model.

This paper presents a method of determining the anisotropic friction model for sheet metal forming processes based on experimental data obtained from the pin-on-disk tribometer test. The anisotropic friction model corresponded to experimental results was implemented into a finite element (FE) model built using the ABAQUS software. In the numerical investigations the hemispherical contact against an elastic-plastic flat was analysed.

\section{Experimental procedure}

The frictional experiments presented in this work were conducted for deep drawing quality (DDQ) cold-rolled steel sheet with a sheet thickness of $1 \mathrm{~mm}$. The mechanical properties of the sheet metal (tab. 1.) have been determined through uniaxial tensile tests along three directions with respect to the rolling direction. The parameters $C$ and $n$ in Hollomon equation have been fitted on stress-strain curve of the tensile test. The anisotropy of plastic behaviour of sheet metals is characterized by the Lankford's coefficient $r$ [7]. A measured $r$-value that differs from unity shows that there is a difference between mechanical properties measured in plane and through-thickness, which is usually characterized by the normal plastic anisotropy ratio. The sheet metal exhibits in-plane anisotropy in the yield stress and the $r$ value, while the hardening exponent value is not significantly affected by the sample orientation. The $r$ value in the rolling direction is smaller than measured value in the transverse direction because it is inversely proportional to the thickness strain. The accommodation of strain in 
the width of the specimen is easier if the basal planes are more tilted to the width direction of the specimen.

Table 1. Mechanical properties of DDQ steel sheet metal

\begin{tabular}{|c|c|c|c|c|c|}
\hline Orientation & $\begin{array}{c}\text { Yield } \\
\text { stress } \boldsymbol{R}_{\boldsymbol{e}} \\
{[\mathrm{MPa}]}\end{array}$ & $\begin{array}{c}\text { Ultimate } \\
\text { tensile } \\
\text { strength } \boldsymbol{R}_{\boldsymbol{m}} \\
{[\mathbf{M P a}]}\end{array}$ & $\begin{array}{c}\text { Hardening } \\
\text { coefficient } \boldsymbol{C} \\
{[\mathrm{MPa}]}\end{array}$ & $\begin{array}{c}\text { Strain } \\
\text { hardening } \\
\text { exponent } \boldsymbol{n}\end{array}$ & $\begin{array}{c}\text { Lankford's } \\
\text { coefficient } \boldsymbol{r}\end{array}$ \\
\hline $0^{\circ}$ & 162 & 310 & 554 & 0.21 & 1.55 \\
\hline $45^{\circ}$ & 163 & 322 & 542 & 0.20 & 1.27 \\
\hline $90^{\circ}$ & 168 & 312 & 530 & 0.21 & 1.67 \\
\hline
\end{tabular}

The friction properties of the deep drawing quality steel sheets used in the experiments were determined by using the pin-on-disc tribometer T01-M (fig. 1.) [8]. The device ensures to carry out investigations in accordance with ASTM G99 and DIN 50324 standards. The values of friction coefficient were determined in dry friction conditions. Prior to each test, the pin and disks were degreased using acetone to remove metal fragments and oil from the surface. The tests were conducted under the following conditions:

- indenter: a ball with the diameter of $5 \mathrm{~mm}$,

- speed of sample rotation $\omega: 36 \mathrm{rpm}$,

- tangential velocity: $0.04 \mathrm{~m} \cdot \mathrm{s}^{-1}$,

- loading weight: $11.77 \mathrm{~N}$,

- track: circle of radius $R=10 \mathrm{~mm}$.

Fig. 1. The general scheme of the measurement

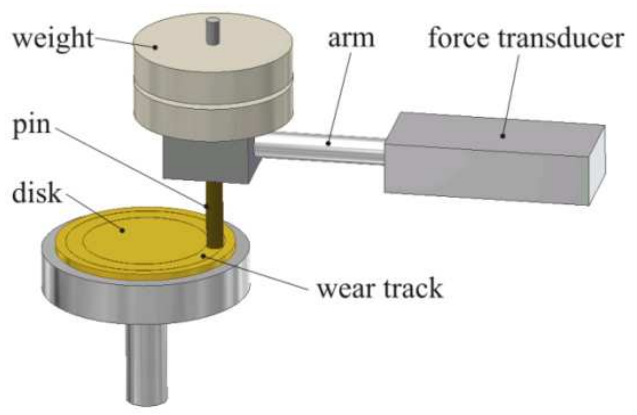

Cyclical nature of the friction contact of pin-on-disk surfaces during tribometer test is the reason for the accumulation of wear products [9] and, consequently, may lead to a seizure of mating surfaces so the friction coefficients were determined for first sample rotation using the formula: 


$$
\mu=\frac{F_{T}}{F_{N}},
$$

where $F_{T}$ - friction force, $F_{N}$ - pin loading force.

To confirm that steel sheets are characterized by the anisotropy of tribological properties, friction anisotropy on a given surface has to be clearly distinguished from friction anisotropy for different perpendicular orientations between the pin and the surface. As shown in fig. 2., changes of friction coefficient value exhibit two maxima for a rotation through $360^{\circ}$. They correspond to the measurement of friction coefficient value transverse to the rolling direction.

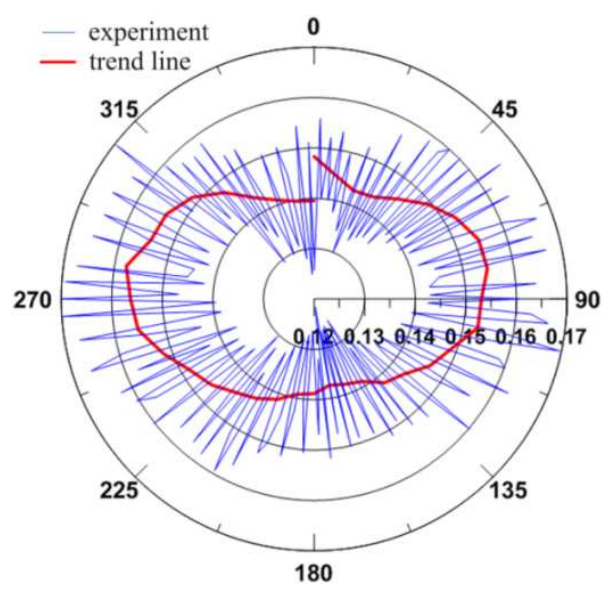

Fig. 2. The variation of friction coefficient value as a function of measurement orientation $\left({ }^{\circ}\right)$ according to the rolling direction of sheet, dry friction conditions

\section{Elastic-plastic analytical analysis}

It was concluded that relation between mean pressure and penetration depth of tribometer's indenter follows a power law. For a non-linear elastic-plastic material with strain hardening described by the Hollomon's equation $\sigma_{p}=C \cdot \varepsilon^{n}$ relation between mean pressure and contact radius equals [10]:

$$
p_{a v}=\alpha \beta^{n} C\left(\frac{a}{D}\right)^{n}
$$

where $\alpha=2.8$ and $\beta=0.4$ are the universal material constants with the values proposed by Tabor [11], $D$ is a sphere diameter and $a$ is a contact radius evaluated from the formula: 


$$
a=\sqrt{h D \frac{5(2-n)}{2(4+n)}},
$$

where $h$ is a permanent penetration depth.

It was assumed by Hill et.al. [10] that the indenter is approximated by a paraboloid, and the indentation profile $w(r)$ could be described by the formula:

$$
w(r)=h-\frac{r^{2}}{D},
$$

for $r \leq a$.

As stated Kucharski and Mróz [12] for elasto-plastic analysis of the indentation test there are more geometrical parameters available (fig. 3.): depths of penetration $h_{t}$ and $h_{p}$ in the loaded state and after unloading, respectively; similarly $a_{t}$ and $a_{p}$ denote the contact radii in the loaded and unloaded states.

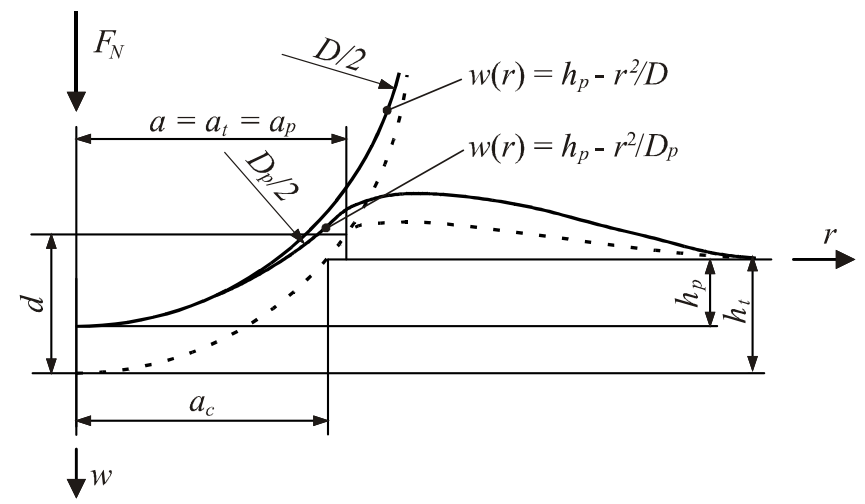

Fig. 3. Loaded and unloaded configuration in the ball indentation

Adler and Dogan [13] provided the variation of the indentation curvature during unloading as:

$$
p_{a v}=\alpha \beta^{n} C\left(\frac{a}{D_{p}}\right)^{n},
$$

where $D_{p}$ is equals:

$$
D_{p}=\frac{D \cdot D_{e}}{D_{e}-D},
$$


and $D_{e}$ specified Hertz solution [14] for elastic unloading:

$$
D_{e}=\frac{8 a E}{3 \pi p_{a v}\left(1-v^{2}\right)} .
$$

Field and Swain [15] renounced the measurement of $a$ and introduced the contact radius $a_{c}$ (fig. 3.) specified at the level of the undeformed surface:

$$
a_{c}=\sqrt{D h-h^{2}} .
$$

\section{Numerical modeling}

In the numerical investigations the elastic-plastic hemispherical contact against an elastic-plastic flat was analysed. Symmetry of the process was utilized in order to reduce the computational time. Only one quarter of blank and the ball (fig. 4.) with symmetry boundary conditions were modeled. As shown in fig. 4. only the indentation test was analysed. Neither sheet nor ball rotation was considered. anisotropic friction model corresponded to experimental results was implemented into a finite element (FE) model built using the commercial FEpackage ABAQUS. The variation of friction coefficient was not uniform along the friction track (fig. 2.). As it was found in previous investigations [16] the anisotropic elliptic friction model approximates well the experimental variations of friction coefficient value. The minimal and maximal values of friction coefficient in implemented elliptic model were 0.128 and 0.157 , respectively. For the isotropic frictional conditions an average value of friction coefficient 0.1425 was used.

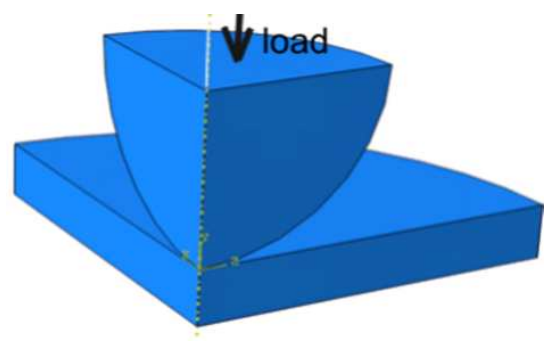

Fig. 4. Numerical model of ball indentation test

The ball was made from bearing steel with hardness considerably larger in comparison with the sheet material. So the material of the ball was assumed as elastic. An elastic-plastic material model of sheet was implemented. The elastic behavior is specified in numerical simulations by the value of Young's modulus, $E=210000 \mathrm{MPa}$, and of Poisson's ratio $v=0.3$. In the numerical model, the anisotropy of the material has been established using Hill (1948) yield criterion [17] which is the most frequently used yield function for steel sheet metals [7]. 
Furthermore, the isotropic Huber-Mises-Hencky material model is considered. The isotropic hardening behaviour in the FEM model uses the Hollomon powertype law.

For the blank and hemisphere meshing the 3-dimensional 8-node brick elements were used. The hardness of the indenter is considerably higher than the blank hardness so the hemisphere is considered to be elastic, no plastic deformation is assumed in this part during the simulation. The blank model is composed of 22880 of C3D8R type elements. The least length of the element edge was $0.004065 \mathrm{~mm}$.

Calculations were performed using the implicit finite element code where the internal forces were balanced with the external forces through an iterative procedure, which gave the deformed state after a time increment. One of the merits of this method is that the time increment can be relatively large because of conditional stability of the implicit time integrator and static solutions can be obtained by natural characteristics of the method.

The influence of mesh size on the accuracy of numerical results was not considered. It is generally known, that the model with high number of elements gives more accurate results. The mesh density of the model assures to get the results in reasonable time.

\section{Results and discussion}

The small errors could be attributed to the averaging of the stress data from integration points to boundary nodes and the discretization of the continuous surface. As the pin load increases, the plastic zone continues to grow until the edge of the plastic zone reaches the surface near the edge of the contact radius. The maximum value of equivalent plastic strain is found at the subsurface, some distance below the centre of the contact region (fig. 5.). The anisotropy of both material and friction conditions was influenced on non-uniformity of the stress distribution around the pin axis, which was clearly visible for higher values of ball indentations. As shown in fig. 6. the change of isotropic friction to anisotropic conditions for both material models slightly influenced on the change of equivalent plastic strain distribution. Similar dependence is observed for equivalent plastic strain value measured along the rolling direction and transverse to the rolling direction (fig. 7.). As the load increases, for both material models, the plastic zone continues to grow until the edge of the plastic zone reaches the surface near the edge of the contact radius. Furthermore, the zone of maximum equivalent plastic strain moves radially from the centre towards the surface inside the maximum contact radius which is in agreement with the analytical results of research made by Kral et.al. [18]. 


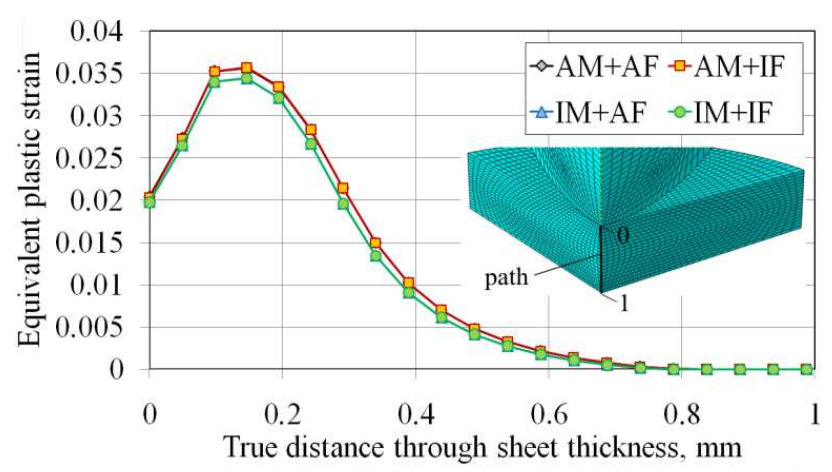

Fig. 5. The distribution of equivalent plastic strain through the sheet thickness
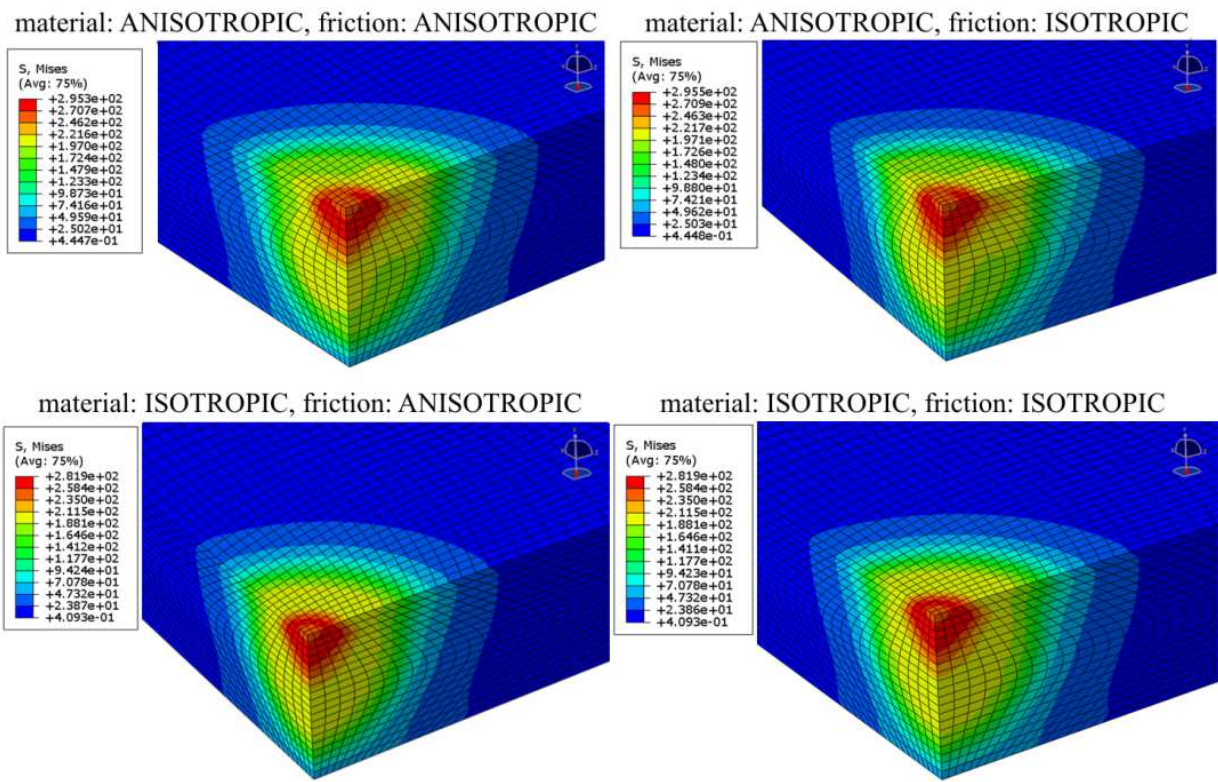

material: ISOTROPIC, friction: ISOTROPIC
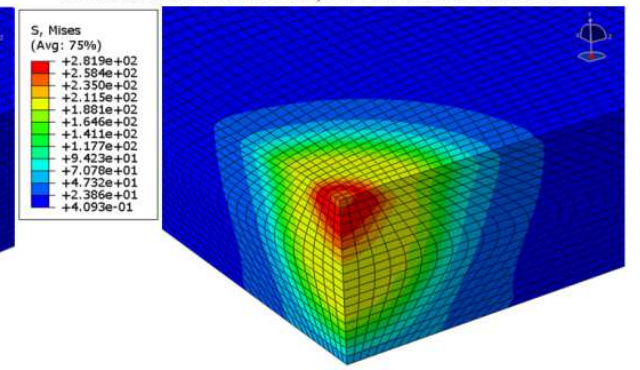

Fig. 6. Distribution of equivalent stress in the sheet for ball indentation $0.018 \mathrm{~mm}$

\section{Conclusions}

The experimental results of friction tests show that the friction coefficient depends on the measured angle from the rolling direction and corresponds to the surface topography. The anisotropic friction model corresponded to experimental results was implemented into a finite element model. In the numerical model, the anisotropy of the material has been established using Hill [17] yield criterion. Furthermore, the isotropic Huber-Mises-Hencky material model is considered. The simulations of pin indentation show that as the load increases, 
the plastic zone continues to grow until the edge of the plastic zone reaches the surface near the edge of the contact radius. Furthermore, as the pin load increases, for both material models, the plastic zone continues to grow until the edge of the plastic zone reaches the surface near the edge of the contact radius. It was found that the change of isotropic friction to anisotropic conditions for both material models slightly influences the change of equivalent plastic strain distribution.

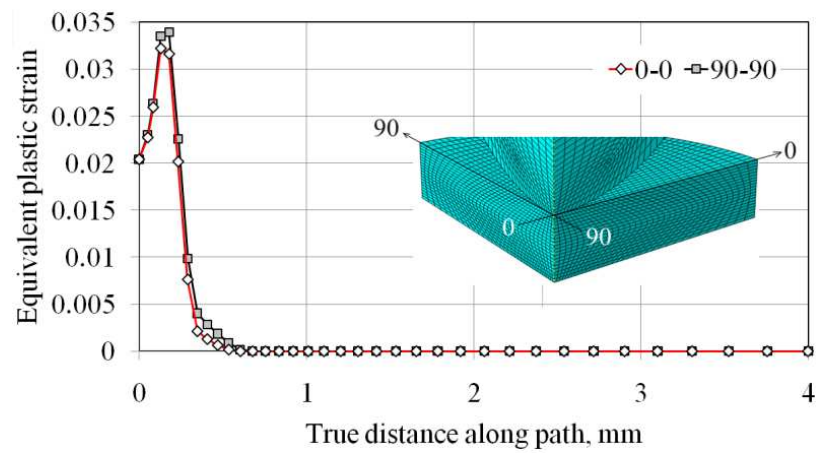

Fig. 7. The distribution of equivalent plastic strain measured along the rolling direction (0-0) and transverse to the rolling direction rolling (90-90)

\section{References}

[1] Trzepieciński T.: Analysis of the friction influence on change of surface topography in strip drawing test. Tribologia, 44, 1 (2012), 125-134.

[2] Gierzyńska M.: Tarcie, zużycie i smarowanie w przeróbce plastycznej metali. WNT, Warszawa 1983.

[3] Hirpa G. Lemu, Trzepieciński T.: Numerical and experimental study of the frictional behaviour in bending under tension test. Stroj. Vest. - J. Mech. Eng., 59, 1 (2013), 41-49.

[4] Hjiaj M., Feng Z.-Q., de Saxcé G., Mróz Z.: On the modelling of complex anisotropic frictional contact laws, Int. J. Eng. Sci., 42, 10 (2004), 1013-1034.

[5] Mróz Z., Stupkiewicz S.: An anisotropic friction and wear model. Int. J. Solids Struct., 31, 8 (1994), 1113-1131.

[6] Chatterje B., Sahoo P.: Effect of strain hardening on elastic-plastic contact of a deformable sphere against a rigid flat under full stick contact condition. Advances in Tribology, vol. 2012 (2012), Article ID 472794.

[7] Banabic D., Bunge H.-J., Pohlandt K., Tekkaya A.E.: Formability of metallic materials. Springer-Verlag, Berlin 2000.

[8] Stachowicz F., Trzepieciński T.: Opory tarcia podczas kształtowania blach karoseryjnych. Mat. Konf. SAKON, Przecław 2003, 297-302.

[9] Godfrey D.: Friction oscillations with a pin-on-disc tribometer. Tribol. Int., 28, 2 (1995), 119-126.

[10] Hill R., Storakers B., Zdunek A.B.: A theoretical study of the Brinell hardness test. Proc. R. Soc. Lond., 423, 1865 (1989), 301-330. 
[11] Tabor D.: The hardness of metals. Clarendon Press, Oxford 1951.

[12] Kucharski S., Mróz Z.: Identification of plastic hardening parameters of metals from spherical indentation tests. Mat. Sci. Eng., A318, 1-2 (2001), 65-76.

[13] Adler T.A., Dogan O.N.: Damage by indentation and single impact of hard particles on a high chromium white cast iron. Wear, 203-204 (1997), 257-266.

[14] Hertz H.R.: On contact between elastic bodies. Collected Works, 1, 1882.

[15] Field J.S., Swain M.V.: Determining the mechanical properties of small volumes of material from submicrometer spherical indentations. J. Mater. Res., 10 (1995), 101 112.

[16] Trzepieciński T., Gelgele H.L.: Investigation of anisotropy problems in sheet metal forming using finite element method. Int. J. Mater. Form., 4, 4 (2011), 357-369.

[17] Hill R.: A theory of the yielding and plastic flow of anisotropic metals, Proceedings of the Royal Society of London, 193 (1948), 281-297.

[18] Kral E.R., Komvopoulos K., Bogy D.B.: Elastic-plastic finite element analysis of repeated indentation of a half-space by a rigid sphere. J. Appl. Mech. - Trans. ASME, 60, 4 (1993), 829-841.

\section{Acknowledgement}

This paper is the result of project implementation: „Trans-Atlantic Micromechanics Evolving Research: Materials containing inhomogeneities of diverse physical properties, shapes and orientations" supported by FP7-PEOPLE-2013-IRSES Marie Curie Action „International Research Staff Exchange Scheme”.

\section{ANALIZA NUMERYCZNA 3D KONTAKTU POWIERZCHNI PÓŁKULISTEJ Z PŁASZCZYZNĄ SPRĘŻYSTO-PLASTYCZNĄ}

\section{Streszczenie}

Artykuł prezentuje metodę wyznaczania anizotropowego modelu tarcia dla procesów kształtowania blach na podstawie danych eksperymentalnych otrzymanych w próbie trobotestera o skojarzeniu trzpień na tarczy. Badania tarciowe przedstawione w pracy wykonano dla zimnowalcowanych blach stalowych głęboko tłocznych. Anizotropowy model tarcia odpowiadający wynikom eksperymentalnym zaimplementowano do modelu elementów skończonych z wykorzystaniem programu ABAQUS. W badaniach numerycznych analizowano kontakt powierzchni półkulistej ze sprężysto-plastyczną powierzchnią płaską. Anizotropia materiału oraz tarcia wpływa na nierównomierność rozkładu naprężeń dookoła osi półkuli, co jest wyraźnie widoczne dla większych zagłębień bryły półkulistej. Zmiana modelu tarcia z izotropowego na anizotropowy nieznacznie wpływa na wartość i zmianę rozkładu naprężeń oraz odkształceń zastępczych w strefie kontaktu.

Słowa kluczowe: anizotropia, modelowanie kontaktu, kontakt sprężysto-plastyczny, modelowanie tarcia, anizotropia tarcia

DOI: $10.7862 / \mathrm{rm} .2014 .65$

Otrzymano/received: $10.10 .2014 \mathrm{r}$.

Zaakceptowano/accepted: 22.11.2014 r. 